\title{
18F-FDG PET/CT HELPS TO FIND OCCULT CARCINOMA IN A PATIENT WITH MULTIPLE BREAST MASSES AT MAGNETIC RESONANCE IMAGING PET/CT com 18F-FDG ajuda a identificar carcinoma oculto em paciente com múltiplos nódulos mamários na ressonância magnética
}

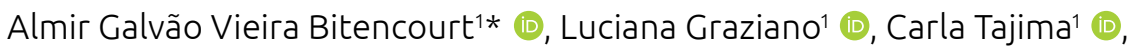 \\ Fabiana Baroni Makdissi (D), Eduardo Nóbrega Pereira Lima' (1)
}

\section{ABSTRACT}

52-year-old female patient with diagnosis of invasive carcinoma in the left breast and metastatic lymph node in the right axilla. Magnetic resonance imaging showed multiple breast masses, with four previous negative biopsies in the right breast. 18F-FDG positron emission tomography (PET)/computed tomography (CT) was performed in prone position, dedicated to breast evaluation. It showed increased uptake in a mass in the right breast. After PET/magnetic resonance imaging (MRI) fusion and second-look breast ultrasound, this mass was submitted to percutaneous biopsy, which confirmed a second invasive breast carcinoma and changed patients' treatment. This is an example of how PET/MRI dedicated devices can improve the evaluation of selected breast lesions.

KEYWORDS: positron-emission tomography; fluorodeoxyglucose F18; magnetic resonance imaging; breast neoplasms.

\section{RESUMO}

Paciente do sexo feminino, de 52 anos, com diagnóstico de carcinoma invasivo na mama esquerda e linfonodo metastático na axila direita. A ressonância magnética mostrou múltiplos nódulos mamários bilaterais, com quatro biópsias anteriores negativas na mama direita. 18F-FDG PET/tomografia computadorizada (CT) foi realizado em decúbito ventral, dedicada à avaliação das mamas, demonstrou aumento da captação em um nódulo na mama direita. Depois de fusão das imagens do PET/CT com a ressonância magnética (RM) e ultrassonografia direcionada, esta lesão foi submetida à biópsia percutânea, que confirmou um segundo carcinoma invasivo na mama direita, alterando o tratamento. Este é um exemplo de como os dispositivos dedicados de PET/RM podem melhorar a avaliação das lesões mamárias selecionadas.

PALAVRAS-CHAVE: tomografia por emissão de pósitrons; fluordesoxiglucose F18; imagem por ressonância magnética; neoplasias da mama.

\footnotetext{
${ }^{1}$ A.C. Camargo Cancer Center - São Paulo (SP), Brazil.
}

*Corresponding author: almir.bitencourt@accamargo.org.br

Conflict of interests: none.

Received on: 01/03/2019. Accepted on: 01/24/2019. 
A 52-year-old female patient presented with a diagnosis of invasive carcinoma in the left breast and metastatic lymph node in the right axilla. Breast magnetic resonance imaging (MRI) showed multiple breast masses (Figure 1), with four previous negative biopsies in the right breast. The 18F-FDG positron emission tomography (PET)/computed tomography (CT) was performed in prone position (Figure 2), dedicated to breast evaluation. It showed increased uptake on the lymph node in the right axilla (standard uptake value (SUV): 4.9) in the left breast carcinoma (SUV: 1.9) and in a mass in the right breast upper outer quadrant (SUV:1.8). After PET/MRI fusion (Figure 2) and second-look breast ultrasound (Figure 3), the right breast mass was identified and submitted to percutaneous biopsy, which confirmed a second invasive breast carcinoma.

PET-CT has a proven role in the staging and treatment evaluation of patients with metastatic breast cancer ${ }^{1,2}$. However, its role in the assessment of primary breast lesions is still controversial, because both benign and malignant conditions may show glucose hypermetabolism ${ }^{3}$. Prone 18 F-FDG PET/CT has a high specificity for the diagnosis of invasive breast carcinomas and allows fusion with breast MR images, which can improve

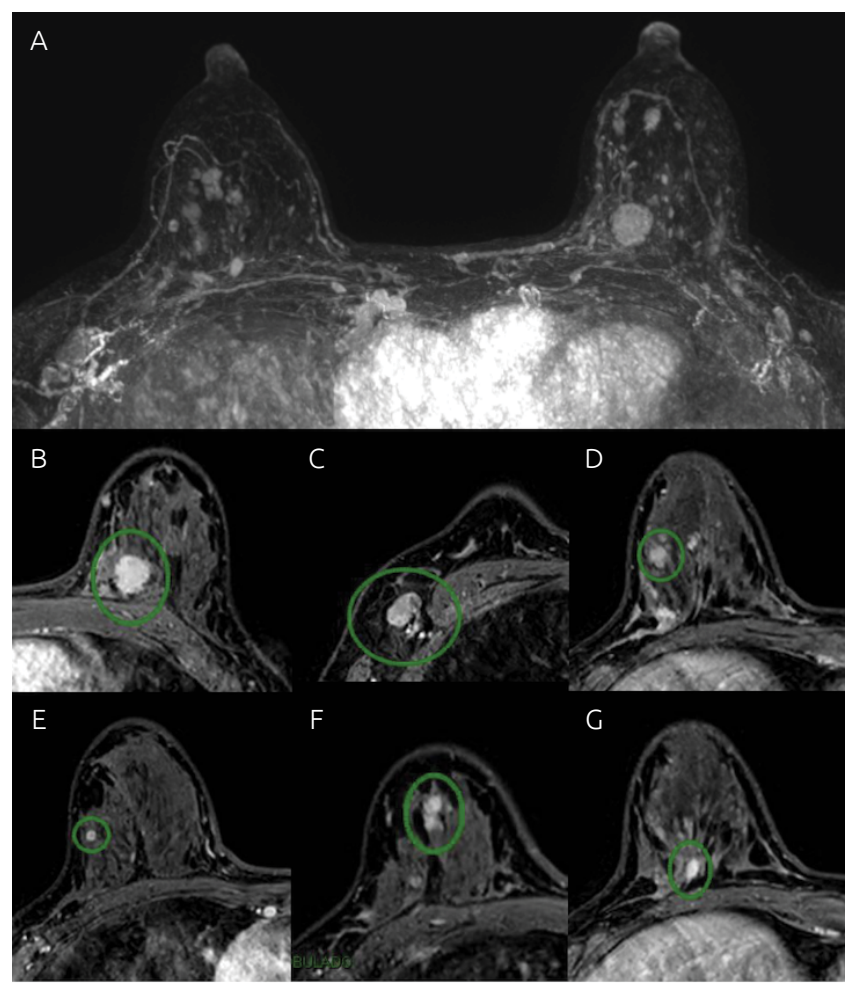

Figure 1. Breast magnetic resonance imaging. (A) 3D maximum intensity projection (MIP) axial reconstruction of a post-contrast subtracted sequence shows multiple breast masses in both breasts. (B) Detail of the known malignant breast carcinoma in the left breast. (C) Detail of the metastatic lymph nodes in the right axilla. (D-G) Detail of the largest masses in the right breast.
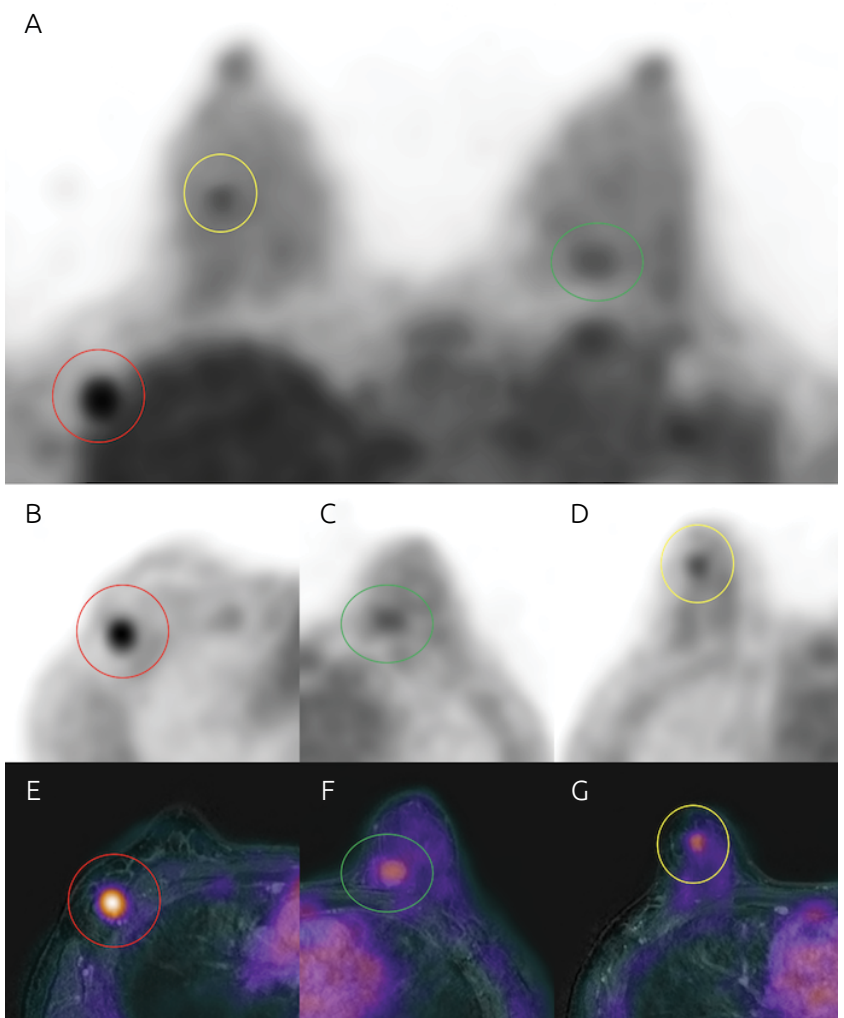

Figure 2. Prone 18F-FDG positron emission tomography (PET) and PET/magnetic resonance imaging (MRI) fusion. (A) 3D axial reconstruction of $P E T$ images shows increased uptake on the lymph node in the right axilla (red circle), in the left breast carcinoma (green circle), and in a mass in the right breast upper outer quadrant (yellow circle). (B-D) Detail of the hypermetabolic areas on PET images. (E-G) PET-MRI fusion images.

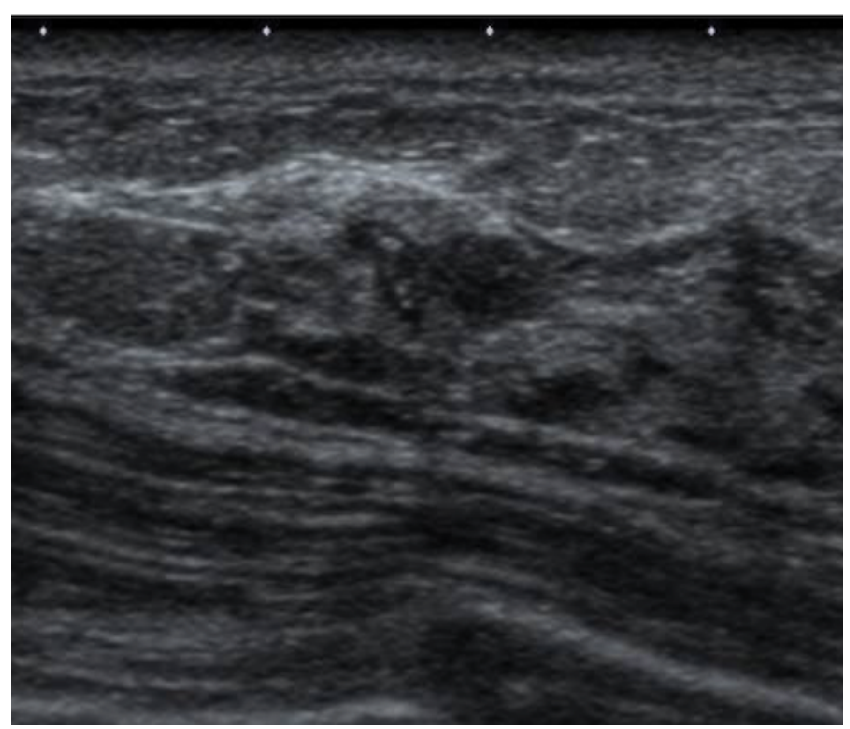

Figure 3. Second-look ultrasound shows an irregular hypoechoic mass in the right breast upper outer quadrant, which corresponds to the hypermetabolic mass found at the PET/computed tomography. 
evaluation of indeterminate breast lesions found on the MRI, especially for mass lesions with a diameter larger than $10 \mathrm{~mm}^{4-8}$. This method can be used for helping to choose what lesion to biopsied when there are multiple breast lesions and high suspicion of malignancy. Because low-grade and small breast carcinomas may have only mild increase in glucose metabolism, any area of increased 18F-FDG uptake in relation to the normal breast parenchyma should be considered suspicious ${ }^{6-8}$.
In the presented case, the right axilla lymph node was a left breast carcinoma metastasis, which would be considered as a distant metastasis for purposes of staging and management. However, PET/CT helped to find a second invasive carcinoma in the right breast, which changed patients' staging, prognosis, and treatment. This is an example of how PET/MRI dedicated devices can improve the evaluation of breast lesions in the selected cases.

\section{REFERENCES}

1. Groheux D, Cochet A, Humbert O, Alberini JL, Hindié E, Mankoff D. ${ }^{18}$ F-FDG PET/CT for Staging and Restaging of Breast Cancer. J Nucl Med. 2016;57(Suppl. 1):17S-26S. https:// doi.org/10.2967/jnumed.115.157859

2. Garcia JR, Pérez C, Bassa P, Capdevilla L, Ramos F, Valenti V. 18F-FDG PET/CT in the Staging and Management of Breast Cancer: Value in Disease Outcome and Planning Therapy. Clin Nucl Med. 2017;42(3):191-2. https://doi.org/10.1097/RLU.0000000000001512

3. Dong A, Wang Y, Lu J, Zuo C. Spectrum of the Breast Lesions With Increased 18F-FDG Uptake on PET/CT. Clin Nucl Med. 2016;41(7):543-57.https://doi.org/10.1097/RLU.0000000000001203

4. Moy L, Ponzo F, Noz ME, Maguire GQ Jr., Murphy-Walcott AD, Deans AE, et al. Improving specificity of breast MRI using prone PET and fused MRI and PET 3D volume datasets. J Nucl Med. 2007;48(4):528-37.

5. Garcia-Velloso MJ, Ribelles MJ, Rodriguez M, FernandezMontero A, Sancho L, Prieto E, et al. MRI fused with prone
FDG PET/CT improves the primary tumour staging of patients with breast cancer. Eur Radiol. 2017;27(8):3190-8. https://doi. org/10.1007/s00330-016-4685-8

6. Magometschnigg HF, Baltzer PA, Fueger B, Helbich TH, Karanikas G, Dubsky P, et al. Diagnostic accuracy of (18)F-FDG PET/CT compared with that of contrast-enhanced MRI of the breast at 3 T. Eur J Nucl Med Mol Imaging. 2015;42(11):1656-65. https://doi.org/10.1007/s00259-015-3099-1

7. Bitencourt AG, Lima EN, Chojniak R, Marques EF, Souza JA, Andrade WP, et al. Can 18F-FDG PET improve the evaluation of suspicious breast lesions on MRI? Eur J Radiol. 2014;83(8):13816. https://doi.org/10.1016/j.ejrad.2014.05.021

8. Moy L, Noz ME, Maguire GQ Jr., Melsaether A, Deans AE, Murphy-Walcott AD, et al. Role of fusion of prone FDGPET and magnetic resonance imaging of the breasts in the evaluation of breast cancer. Breast J. 2010;16(4):369-76. https:// doi.org/10.1111/j.1524-4741.2010.00927.x 